\title{
Criminalising oppression or reinforcing oppression? The implications of veil ban laws for Muslim women in the West \\ NeIL Chakraborti
}

Senior Lecturer in Criminology, University of Leicester

AND

IRENE ZEMPI

PhD Student and University Tutor, University of Leicester

\begin{abstract}
$\mathrm{I}^{\mathrm{n}}$ n a post-9/11 climate, certain European countries have applied restrictive measures and bans on the practice of Islam in the public sphere. Such bans involve the hijab (headscarf) and the niqab (face veil), as well as minarets. ${ }^{1}$ In 2004, the French government passed a law that banned the wearing of 'ostentatious' religious symbols in public schools. ${ }^{2}$ The law on 'secularity and conspicuous religious symbols' was an amendment to the French Code of Education that expanded principles founded in the then existing French law, especially the constitutional requirement of laïcité: the separation of religion and state. Although prohibited items included a large cross, a Sikh turban and a yarmulke (a head-covering worn by Jewish men and boys), the main effect was to ban the headscarf on the basis that this law predominately applied to Muslim girls. In a post-9/11 context, the Muslim headscarf has greater symbolic resonance than other 'ostentatious' markers of religious identity, and correspondingly political, media and public debates have been chiefly concerned with the Muslim headscarf. In April 2011, France became the first country in Europe to introduce a law banning the wearing of the face veil in public places including public buildings, educational institutions, hospitals and on public transport. ${ }^{3}$
\end{abstract}

Although France's Constitutional Court ruled that the veil ban does not illegitimately restrict human rights, ${ }^{4}$ the court made a change to the law as it was passed by the French legislature, in that the ban would not apply to public places of worship where it might violate religious freedom. ${ }^{5}$ Under the new law, women who wear face veils in public places in France are subject to fines of $€ 150$ and/or participation in citizenship education. The law also penalises, through a fine of $€ 30,000$ and one year in prison, anyone who forces another to wear face-coverings in public; these penalties may be doubled if the victim is under the age of 18 . Belgium was the second European country after France to enforce a similar ban.

1 Thus, for instance, Switzerland has banned the construction of new mosque minarets on the basis that minarets are a sign of Islamisation. In November 2009, Swiss voters supported a referendum proposal to ban the building of minarets. More than 57 per cent of voters and 22 out of 26 provinces voted in favour of the referendum.

2 French law number 2004-228 of 15 March 2004.

3 French law number 2010-1192 of 11 October 2010.

4 The French Constitutional Council ruled that the Bill, which makes it illegal to wear full-face veils in public, conforms to the French Constitution. For more information see decision of 7 October $2010<$ www.conseilconstitutionnel.fr/conseil-constitutionnel/root/bank/download/cc-2010613dc.pdf>.

5 'French Ban Clears Last Legal Battle' (BBC News, 7 October 2010) <www.bbc.co.uk/news/world-europe11496459>. 
Under Belgian law, 'offenders' (that is, Muslim women in veil) face a fine of $€ 137$ and up to seven days of imprisonment. Following the example set by France and Belgium, the Dutch government has now agreed to introduce a ban on face-covering in public, so making the Netherlands the third country in Europe to prohibit the face veil. Countries such as Austria, Denmark, Norway, Switzerland and Spain are considering similar legislation, whilst in northern Italy, an old anti-terrorist law against concealing the face for security reasons has been used by some local authorities to fine Muslim women who wear face veils. ${ }^{6}$ Other European states ${ }^{7}$ have also sought bans on religious dress in the context of state employment and educational institutions though no other country except France and Belgium as yet has criminalised the Muslim veil.

Although the UK does not have any legislative prohibitions in place, there are calls for such legislation to be introduced. For instance, the Conservative MP Philip Hollobone sought to introduce a Private Members' Bill entitled the Face Coverings Regulations Bill which would make it illegal for people to cover their faces in public. The Bill, which received its second reading in the House of Commons in December 2011, was rejected. ${ }^{8}$ The British National Party and the UK Independence Party both supported a veil ban in their most recent election manifestos, ${ }^{9}$ and extremist groups such as the English Defence League including its offshoot divisions, namely the Scottish Defence League and the Welsh Defence League - have staged a number of violent anti-Muslim protests against elements of Islam such as Sharia law, mosques and the Muslim veil. The comments in 2006 of the then Secretary of State for Justice Jack Straw attracted considerable publicity when he stated that the face veil is a 'visible statement of separation and of difference' that can weaken community relations, ${ }^{10}$ as did those of Tony Blair, the then Prime Minister, who described the wearing of the face veil as a 'mark of separation' in 2006.11

This article critically assesses the implications of the French veil ban and its emotional impact upon veiled Muslim women in the West. Using legislation to ban the veil has serious human rights implications, particularly when it contravenes freedom of religious practice and freedom of expression. Seen in this light, the ban adopts a patriarchal ideology in order to justify and rationalise Islamophobic understandings of the veil. Within this framework, our article is premised on three lines of argument. First, we argue that the veil ban prevents veiled Muslim women from full participation in society by exacerbating their multiple and intersectional discrimination on the grounds of both religion and gender, thereby increasing (rather than decreasing) social exclusion by pushing these women to the margins of society. Secondly, we suggest that this law stigmatises veiled women as 'criminals', thereby potentially 'legitimising' acts of violence towards them when they are spotted in public. In this sense, the veil ban increases the sense of vulnerability of Muslim women dressed in

6 'The Islamic Veil Across Europe' (BBC News, 22 September 2011) <www.bbc.co.uk/news/world-europe13038095>.

7 Eight out of Germany's 16 states (Baden-Württemberg, Bavaria, Hesse, Lower Saxony, Saarland, Bremen, North Rhine-Westphalia and Berlin) have enacted legislation to prohibit the wearing of hijabs by teachers and, in some states, by civil servants and law enforcement officers. See Human Rights Watch, Discrimination in the Name of Neutrality: Headscarf Bans for Teachers and Civil Servants in Germany (Human Rights Watch 2009).

8 'MP Philip Hollobone's Planned Law to Ban Wearing the Burka in Public is Binned by Parliament' Birmingham Mail (Birmingham, 20 January 2012) <www.birminghammail.net/news/uk-news/mp-philip-hollobonesplanned-law-8737>.

9 'Socialist Resistance Statement on the Banning of the Veil' Links (26 July 2010) $<$ http://links.org.au/node/1809>.

10 M Taylor and V Dodd, 'Take off the Veil, says Straw - To Immediate Anger from Muslims' The Guardian (London, 6 October 2006) <www.guardian.co.uk/politics/2006/oct/06/immigrationpolicy.labour>.

11 'Blair's Concerns over Face Veils' (BBC News, 17 October 2006) < http://news.bbc.co.uk/1/hi/6058672.stm>. 
niqab in the public sphere. Thirdly, we argue that this law - as an example of ideological Islamophobia - affects the wider Muslim community. ${ }^{12}$ We conclude by noting that the effects of the veil ban policy are not exclusively restricted to women who adhere to Muslim codes of dress and the Muslim community; rather, the harm extends to society as a whole on the basis that this law attacks the fundamental value of liberal democratic states: the issue of choice. Before contextualising these individual and collective harms, the article first considers dominant justifications in favour of the veil ban.

\section{Justifications behind the veil ban}

The underlying principle behind the French veil ban is the historical commitment to secularism - laïcité. Though France has been a rigidly secular republic since the French Revolution, French secularism is currently based on the 1905 French law on the separation of church and state. ${ }^{13}$ During the twentieth century, laïité meant equal treatment of all religions; however, a more restrictive interpretation of the term has developed since 2004 when the French government banned conspicuous religious symbols, including the Muslim headscarf, from public schools. ${ }^{14}$ In the current climate, the French interpretation of separation of religion and state forbids the wearing of face veils in public places on the basis that the visibility of veils makes Islam visible in French society. Indeed, Islam is highly visible in the West and the face veil is seen as a powerful marker of difference, an essentialised symbol of a 'traditional' identity associated with being Muslim. Just as veils for women and beards for men are the most obvious personal markers of Islam in the West, so too are mosques clear signs of the growing presence of Islam in the West. Such visible Islamic symbols are perceived to conflict with national identity in European states which promote a shared (non-religious) identity and culture.

Another viewpoint commonly cited in defence of the ban sees the veil as a practice synonymous with religious fundamentalism and, as such, one which fosters political extremism. Accordingly, the veil is perceived as an example of Muslim 'otherness', particularly when linked to the $9 / 11$ and $7 / 7$ terrorist attacks and the global War on Terror. From this perspective, the covering of the face with the Muslim veil is seen as a tool of Islamist fundamentalism in the West and a threat to public safety since the public have no idea who is behind the face-covering - be it male or female. In this context, the conflation between Islam and terrorism accentuates the validity of the hypothesis about the incompatibility between Islam and the West, and about the threat constituted by the settling of Islam in the West. Muslims who visibly profess and practise their religion are routinely labelled 'radicals' whilst those who are non-practising Muslims (or live their faith privately) are seen as 'moderates'. ${ }^{15}$ Within this framework, the wearing of the full veil symbolises the otherness of Islam in the West as it is more visible and thus more 'threatening' to the democratic values of Western societies. As a symbol of Islamist fundamentalism, the veil is interpreted as incompatible with the values and ethos of European society.

Equally, the veil is often understood as a political symbol conflicting with gender equality. ${ }^{16}$ In this context, the veil is seen as an expression of the dissociation from Western

12 In this context, Muslims are led to view themselves as members of a stigmatised and socially excluded population.

13 H Astier, 'The Deep Roots of French Secularism' (BBC News, 1 September 2004 <http://news.bbc.co.uk/ 1/hi/world/europe/3325285.stm>.

14 French law number 2010-1192 (n 3).

15 A Wing and M N Smith, 'Critical Race Feminism Lifts the Veil?: Muslim Women, France and the Headscarf' (2005) 39 UC Davis Law Review 743-78.

16 N Chakraborti and I Zempi, 'The Veil under Attack: Gendered Dimensions of Islamophobic Victimisation' (2012) 18(3) International Review of Victimology 269-84. 
values including the emancipation of women. From this premise, when Muslim women wear the veil it confirms the underdeveloped status of women in radical Islam and symbolises that they accept (or they are forced to accept) all of the conditions that radical Islam mandates. For fundamentalist Muslim men, a hidden female body represents the rejection of a mixed society and the fixing of inequality in gender difference. ${ }^{17}$ Ultimately, the practice of veiling is said to subjugate women and make them 'invisible'. In this context, the veil is seen as a sign of gender oppression, which symbolises belonging to a single man: the Muslim husband. ${ }^{18}$ By this logic, accepting the veil means approving the possession of the female body by fundamentalist Muslim men, and the veil ban therefore pursues the legitimate aim of promoting gender equality and maintaining secularism.

Finally, the wearing of the face veil can be associated with the existence of parallel communities and with the failure of integration. It has been argued that Muslims have attempted to create an Islamic identity which is both visible and naturalised within the Western context through wearing the headscarf and/or the veil, the erection of mosques and loud Islamic calls to prayer. ${ }^{19}$ However, in the eyes of the French state, these activities represent a paradigm of Huntington's 'clash of civilisations' thesis, which posits that Islam and the West are two monoliths that are at war with each other. ${ }^{20} \mathrm{By}$ the veiling of women, Islam is illustrated, interpreted and marked as a completely 'different' world where the veil signifies the border between the 'West' and 'Islam'. ${ }^{21}$ For instance, in 2008, France refused a Muslim woman citizenship because she wore a face veil. Faiza Silmi, whose husband was already a French citizen, had her application rejected on the grounds of insufficient assimilation into France'. 22 On appeal, the French Council of State said that she had 'adopted a radical practice of her religion, incompatible with essential values of the French community, particularly the principle of equality of the sexes'.23 Justifications of this nature are therefore designed to ensure that Muslim females in France become well-assimilated citizens who speak, think and dress in an appropriately 'French' fashion.

\section{The veil ban as a mark of oppression}

The discussions above highlight that there are a variety of intersecting reasons why governments may be persuaded to ban the Muslim veil in public places. These are guided by perceptions of the veil as a symbol of Islamist fundamentalism, of the inferior status of women in Islam and of a lack of willingness to integrate into 'host' countries. However, we would argue that the veil ban operates within an essentialist understanding of Islam that is inherent in the 'clash of civilisations' paradigm. In other words, the veil ban acts as an identifier of a stigmatised community whereby Islam is depicted as a backward religion, Muslim women as oppressed and Muslim men as barbaric. In essence, we argue that the French rejection of the veil is a sign of intolerance, even of Islamophobia. ${ }^{24}$

17 Wing and Smith (n 15).

18 Chakraborti and Zempi (n 16).

19 Wing and Smith (n 15).

20 S P Huntington, The Clash of Civilisations and the Remaking of World Order (Touchstone 1997).

21 E Klaus and S Kassel, 'The Veil as a Means of Legitimisation: An Analysis of the Interconnectedness of Gender, Media and War' (2005) 6(3) Journalism 335-55.

22 See C Skeet, 'Globalisation of Women's Rights Norms: The Right To Manifest Religion and “Orientalism” in the Council of Europe' (2009) 4 Public Space: The Journal of Law and Social Justice 34-73.

23 Ibid.

24 For the purposes of this discussion, Islamophobia is defined as 'a fear or hatred of Islam that translates into ideological and material forms of cultural racism against obvious markers of "Muslimness": Chakraborti and Zempi (n 16) 271. 
As we have seen, one of the most popular justifications in favour of the veil ban is that veiling subjugates women. ${ }^{25}$ Unquestionably, there are some Muslim women and girls who may be subjected to mandatory wearing of the veil by their family or community, and the law in question may serve to protect these women. However, while some may feel pressured, others may decide to wear the veil independently and often against their family's or community's wishes. ${ }^{26}$ Muslim women may choose to wear the veil for many reasons, including personal religious conviction, compliance with family or community values, protection from sexual harassment, desire to express individuality and expression of their religious and cultural identity. Linked to this choice to wear the veil is pride in being a Muslim in a non-Muslim country and also a sign of their affirmation of 'Muslim identity'. In this context, veiling in a non-Muslim country could be a way of asserting a determination to be both European and Muslim through veiling, which is one example of displaying a Muslim identity.

Although gender oppression is one of the factors most commonly linked to the practice of veiling, it could be argued that oppression in this context does not come from the use of the veil as such. Rather, the oppression of veiled women lies in a lack of control over their bodies. This suggests that women who want to adopt the veil out of personal religious conviction may feel morally and legally pressurised to conform by unveiling themselves. In this sense, the veil ban constitutes a form of oppression. In light of the fact that the veil stands as symbolic of Islam, its prohibition can be seen as an example of an attempt by Western European governments to oppress personal expressions of Islamic religion and culture. The justifications for laws of this kind are based on the notion that all Muslim girls and women who wear the veil are forced to do so, which ultimately denies the autonomy of those who are not. Indeed, as we shall see, for Muslim women who want to wear the veil, its prohibition oppresses them and has a significant impact upon their sense of freedom of expression and Muslim identity.

It is important to challenge the idea that the solution to veiled women's 'oppression' lies in banning the veil. Rather, it is in empowering these women to make individual choices about their bodies. The ideal for liberation of veiled women should begin with dismantling the patriarchy that controls their bodies - whether oppressors are Islamist fundamentalists or Western 'liberators'. However, the arguments used to justify the veil ban demonstrate that Islamophobia - as an ideological framework of understanding Islam and Muslims becomes idiomatic within the cultural, political and legal framework of the 'host' society, to the extent that Muslim women who choose to wear the veil are denied their fundamental right to participate as citizens. This reality of oppression has dire consequences for the everyday lived experiences of Muslim women in this position, serving to ostracise them from society, causing them emotional damage and increasing their sense of vulnerability in public places. By invoking the coercive power of law to impose such legislation, the veil ban directly affects the ummah, since what appears to affect only a minority of Muslims will have implications for that community as a whole.

An appreciation of the concept of ummah and its implications has relevance for understanding the community impact of the veil ban. In essence, the notion of ummah reframes the parameters of what defines national identity in Islam and reflects the development of a robust collective identity amongst the world's Muslims, which cannot be adequately explained purely within the framework of religious fellowship. ${ }^{27}$ In the words of

25 Chakraborti and Zempi (n 16).

26 Wing and Smith (n 15).

27 Huntington (n 20). 
Mandeville: 'Muslims living in diaspora - particularly in the West - are of varied and diverse ethnic origins. What links them together, however, is a shared sense of identity within their religion, an idea most clearly located within the concept of the ummah. ${ }^{28}$ The cumulative impact of the veil ban - and its attendant layers of stigmatisation and marginalisation - can be to reinforce the sense of alienation experienced by members of the ummah-based community. This means that the veil ban impacts upon notions of belonging and cohesion amongst Muslims, who are reminded of the appropriate alignment of 'us' and 'them'. At the same time, the veil ban impacts upon notions of safety within the Muslim community by reinforcing the fear that, in the presence of the dominant European identity, Muslims are vulnerable to attacks, harassment and discrimination.

\section{Discrimination and social exclusion}

The veil ban appears to attack Islam through banning a religious piece of cloth which is worn exclusively by Muslim women. In particular, this law does not ban religious symbols per se but exclusively the religious codes of dress adopted by women in Islam. This observation indicates that two types of discrimination weigh on veiled Muslim women in France and Belgium: one forbids them access to the public sphere by virtue of their 'Muslimness' whilst the other isolates them as women. The effect of this is that the law in question explicitly forces veiled Muslim women to choose between their religious convictions and participation in society, violating their right to freedom of religion and to equal treatment. Such policies are not abstract concerns but have a profound effect on veiled Muslim women's lived experiences.

This reality of double discrimination leads to their social exclusion from mainstream society whereby women in veil feel unwelcome and marginalised. In particular, the ban excludes women in veil from the public sphere by creating barriers to accessing mainstream services. According to the Council of Europe's Commissioner for Human Rights, banning veiled women from public places including public institutions, hospitals and government offices may simply result in them avoiding such places altogether, which leads to their alienation from mainstream society. ${ }^{29}$ It is not surprising that, in France, veiled women have been found to experience social isolation and alienation by virtue of being denied access to the public sphere by the society in which they live. ${ }^{30}$

Evidence suggests that there are Muslim women in France who continue to wear the face veil as an act of resistance and non-conformity. ${ }^{31}$ This indicates a deliberate refusal to become part of the mainstream community, prioritising a culture of seclusion over a culture of inclusion. However, it is necessary to bear in mind that for these women veiling is a religious obligation - an act of submission to God. Muslim women who are committed to their faith and who wish to see a visible expression of that commitment expressed in terms of adherence to the Muslim dress code may decide to defy the veil ban. Those women who continue to wear the veil consciously choose to isolate themselves from mainstream society through their refusal to conform to the normative cultural standards or to the dominant identity. The consequence of this is that they deliberately choose not to integrate with nonMuslims by living in separate communities because integration would entail hiding their

28 P Mandaville, 'Communication and Diasporic Islam' in K Karim (ed), The Media of Diaspora (Routledge 2003) 135.

29 T Hammarberg, 'Penalising Women who Wear the Burqa Does not Liberate Them' (19 April 2012) $<$ http://commissioner.cws.coe.int/tiki-view_blog_post.php?postId=157>.

30 Open Society Foundations, Unveiling the Truth: Why 32 Muslim Women Wear the Full-face Veil in France (Open Society Foundations 2011).

31 A Chrisafis, 'France's Burqa Ban: Women are "Effectively under House Arrest" The Guardian (London, 19 December 2011 <www.guardian.co.uk/world/2011/sep/19/battle-for-the-burqa>. 
Muslim identity. Ultimately, a law that bans the veil leaves veiled Muslim women little option but to lead parallel lives in order to protect their religious and cultural identities. At the same time though, a major contributing factor to the problem of Islamophobia and its impact on victims is a failure to recognise the emotional, psychological and, to some extent, physical effects of expressions of Islamophobia on its targets.

\section{Emotional and physical harms}

Muslim women in veil suffer both emotionally and physically because of the law banning the veil in public places and its Islamophobic dimensions. ${ }^{32}$ At an emotional level, the veil ban can be seen as a form of oppression and violation. For Muslim women who want to wear the veil, the ban results in a sense of imprisonment on the basis that it restricts their participation in society. Islamophobia, like its sister oppressions - racism and other forms of hate crime constrains self-development and self-determination and disrupts notions of belonging.

From this perspective, the banning of the veil constitutes a form of 'spirit injury' that negatively affects veiled Muslim women. Spirit injury is the product of the psychological, spiritual and cultural effects of multiple types of racism, sexism and discrimination upon 'other' women, and it can lead to the slow death of a person's soul or psyche. ${ }^{33}$ Muslim women who want to wear the veil but are not permitted to do so by legislation might feel some of the symptoms of spirit injury including 'defilement, silence, denial, shame, guilt, fear, blaming the victim, violence, self-destructive behaviours, acute despair/emotional death'. ${ }^{34}$ Victims might feel responsible for the circumstances that they find themselves in, perhaps without being aware that Islamophobia played a major role. Alternatively, victims might be aware of Islamophobia but might feel helpless to deal with its effects, such as strong feelings of shame and guilt, depression, general anxiety, or various combinations of all these effects. As such, the veil ban may constitute a psychic human rights violation. ${ }^{35}$ All of this suggests that experiences of Islamophobic discrimination can result in psychological and emotional injury.

The levels of psychological and emotional suffering can be devastating for victims. In particular, veiled Muslim women who have been victims of Islamophobia multiple times because of the visibility of their Muslim identity are more likely to be traumatised by the banning of the veil. Empirical studies of targeted victimisation suggest that the emotional, psychological and behavioural impact is more severe for victims of hate crimes when compared to non-hate-crime victims. ${ }^{36}$ The impact of this victimisation may exceed that of 'normal' crime because of victims' perceived and actual vulnerability due to their group membership. Being a member of oppressed and socially marginalised groups often means

32 In some senses it may be somewhat artificial to separate emotional injury from physical forms of abuse: physical forms of abuse also inflict emotional and psychological harm on victims, and both forms of harm serve to establish dominance and control over the female body. However, despite the conceptual and experiential overlap, the various forms of harm are considered separately for the purposes of this discussion.

33 Wing and Smith (n 15).

34 A K Wing and M R Johnson, 'The Promise of a Post-Genocide Constitution: Healing Rwandan Spirit Injuries' (2002) 7 Michigan Journal of Race and Law 247-89.

35 Wing and Smith (n 15).

36 See G Herek, J Cogan and R Gillis, 'Victim Experiences in Hate Crimes Based on Sexual Orientation' (2002) 58(2) Journal of Social Issues 319-39; R Boeckmann and C Turpin-Petrosino, 'Understanding the Harm of Hate Crime' (2002) 58 Journal of Social Issues 207-25; J Garland and N Chakraborti, 'Recognising and Responding to Victims of Rural Racism’ (2006) 13(1) International Review of Victimology 49-69; P Iganski, Hate Crime and the City (Policy Press 2008); J McDevitt, J Balboni, L Garcia and J Gu, 'Consequences for Victims: A Comparison of Bias- and nonbias-motivated assaults' (2001) 4(4) American Behavioral Scientist $697-711$ 
engaging in self-blame and having feelings of confusion, shame and guilt. ${ }^{37}$ In the same way, research on stigmatised populations suggests that the experience of racism and/or discrimination can be a source of chronic stress that may result in negative psychological and physical health outcomes, such as increased blood pressure, anxiety, depression and post-traumatic stress disorder symptoms. ${ }^{38}$ As such, the veil ban may lead to lasting emotional and psychological damage, particularly for repeat victims of Islamophobia.

We have already noted how the veil ban supports a patriarchal discourse which reduces the veil to a symbol of Islamist fundamentalism, gender subjugation and deliberate lack of integration. ${ }^{39}$ Such readings of the veil as a threat may often translate into a series of Islamophobic actions on the ground. According to the French Council of the Muslim Faith, Islamophobia targeted at veiled women is on the rise in France since the passing of laws that ban Muslim women's choice of dress. ${ }^{40}$ In the same way, French Muslim groups report a significant increase in verbal and physical violence against veiled women - such as people in the street taking the law into their hands and trying to remove their veils, bus drivers refusing to carry women who wear the face veil or shop owners trying to bar entry to women in niqab - whilst some police officers face a dilemma on whether to refer the case to a local judge or to simply 'turn a blind eye' when they see women wearing the face veil in public places. ${ }^{41}$ Along similar lines, a recent report which focused on the experiences of veiled Muslim women in France found that almost all of the research participants had experienced verbal abuse, whilst some veiled women had also been physically attacked since the debate on the French ban. ${ }^{42}$ This evidence suggests that Muslim women who wear the veil may experience harassment, verbal and physical abuse from people who see them as 'criminal' following the criminalisation of the face veil in France.

Drawing on Maroney's taxonomy on law and emotions and the intersection of reason and emotion, one could argue that the veil ban compounds the emotional suffering of those affected by it on the basis that it communicates a message of institutionalised Islamophobia through formal power structures of law-making, police procedure, prosecutorial power and governmental policy. ${ }^{43}$ By making the wearing of the face veil a criminal offence, this law promotes a climate of intolerance, even hostility, thereby legitimising violence targeted at veiled Muslim women - be it in terms of violation of human rights, discrimination, or harassment on the street. From this perspective, the veil ban justifies and rationalises a negative discourse that makes women in veil 'easy targets' for verbal abuse and physical attacks when they are spotted in public places. Equally worryingly, the veil ban incites antiIslamic, anti-Muslim hatred not only in those countries where the ban has been enforced but also in other European countries such as the UK, where it is still legal to wear the face veil.

Against the backdrop of heightened concerns about national security, gender equality, secularism, the failure of multiculturalism and the fear of Islamist fundamentalism, the veil ban in France stigmatises the wearing of the veil as dangerous, illegal and thus 'criminal'. Correspondingly, this justifies public manifestations of anti-Muslim hostility towards women who defy this legislation in France and elsewhere in the West, and highlights the

37 E B Carlson, Trauma Assessments: Clinician's Guide (Guilford 1997).

38 D R Williams, H W Neighbors and J S Jackson, 'Racial/Ethnic Discrimination and Health: Findings from Community Studies (2003) 93 American Journal of Public Health 200-08.

39 Chakraborti and Zempi (n 16).

40 Cordoba Foundation, Islamophobia and Anti-Muslim Hatred (2007) 10(7) Arches Quarterly 6-156.

41 Hammarberg (n 29).

42 Ibid.

43 T A Maroney, 'Law and Emotion: A Proposed Taxonomy of an Emerging Field' (2006) 30(2) Law and Human Behavior 119-42. 
ripple effects of this legislation on other Western European countries, where veiled Muslim women are perceived as 'criminals'. In this context, there is a strong link between the French veil ban policy and attacks on veiled women in the UK, as noted in a recent study of Islamophobic victimisation. ${ }^{44}$ This finding is illustrative of the domino effect of European policy, whereby events in one European country can influence public opinion in its neighbouring states. In the words of Yasmin, one of the research participants in the aforementioned study:

France's action has given people in the UK the right to be abusive. Some people feel that they've got the platform and the right to say things that they wouldn't have before. So whereas before they'd keep it quiet and know that British values are different, that we are tolerant and we are very pro-multicultural, the moment France did what they did, suddenly these people thought 'Right, now we've got a voice, now we've got justification, now we can talk because if the government in France thinks veiling is bad, it is ok for us to raise our racist opinions.'

\section{Community implications}

As with any religion and its followers, Islam is increasingly being used by Muslims including those who have converted to Islam - as a basis of identity definition and formation. ${ }^{45}$ However, this rise in Muslim identity is shaped to a certain extent by experiences of Islamophobia. As Muslim identities have been constructed as 'other' to Western European identities, an attempt to distort Muslim identities, or to suppress the symbols of these identities, often has the opposite effect: it strengthens these identities, which in turn has the effect of exacerbating the polarisation which already exists between Islam and the West. ${ }^{46}$ Within this framework, an act of discrimination which is perceived by the individual to be motivated by hatred towards Islam may lead to 'Islam' becoming a more predominant part of the person's self-identity. In light of banning the veil, Islam may become a more salient and important marker of identity in response to attempts made by the state to render Islam invisible. This could be understood as a 'resistance identity'. ${ }^{47}$

The notion of resistance identity indicates the importance of cultural, religious and national identity as sources of meaning for people, and particularly for those social actors who are devalued or stigmatised by the logic of domination. ${ }^{48}$ In assuming a resistance identity, Castells sees such individuals 'building trenches of resistance and survival on the basis of principles different from, or opposed to, those permeating the institutions of society'. ${ }^{49}$ The persistence of popular debates in crystallising Muslims as permanent and essential 'others' - and the well-documented tendency of politicians to use legislation as a comfort blanket to reassure the public that the government is 'doing something' - have contributed to the emergence of an ummah-based community as a response to the current

44 A recent piece of research on the lived experiences of veiled Muslim women in Leicester found that all research participants understood the French veil ban as a trigger event that has led to increased levels of hostility and abuse because of the way they dress in the UK: I Zempi, Unveiling Islamophobia in Leicester: The Victimisation of Muslim Women in Veil (2014 forthcoming).

45 T Modood and F Ahmad, 'British Muslim Perspectives on Multiculturalism' (2007) 24(2) Theory, Culture and Society 187-213.

46 M Brown, 'Multiple Meanings of the Hijab in Contemporary France', in W J F Keenan (ed), Dressed to Impress: Looking the Part (Berg 2001) 105-21.

47 M Castells, The Power of Identity (Blackwell 1996).

48 Ibid.

49 Modood and Ahmad (n 45) 8. 
climate of Islamophobia in the West. ${ }^{50}$ Accordingly, the notion of belonging to the ummah can be an expression of collective resistance to the problem of Islamophobia. In light of the fear and hostility generated by $9 / 11$ and $7 / 7$, the consequential backlash against Muslims worldwide has strengthened this concept particularly amongst those Muslims living outside the Muslim world. The veil ban has come into effect in the age of the War on Terror, where Muslim minorities in Western countries have been facing increasing discrimination in schools, the workplace and society in general whilst all Muslims have been essentialised as terrorists or terrorist sympathisers. ${ }^{51}$

As already mentioned, ideological expressions of Islamophobia - in line with material forms of Islamophobic victimisation - can have psychological and emotional effects including fear, vulnerability and a sense of normativity of discrimination on both direct and indirect victims. In this context, Islamophobia acts as a form of emotional terrorism in that it segregates and isolates Muslims, in terms of restricting their freedom of movement in the public sphere and changing their patterns of social interaction. Thus, the tangible fear of being assaulted and abused limits pivotal aspects of identity-building, such as visiting friends, going to college, or attending the Mosque. ${ }^{52}$ For Perry and Alvi, this is not a voluntary choice, but the 'safe' choice. ${ }^{3}$ They argue that whether individually or collectively, the reality of Islamophobia creates social and geographical yet 'invisible' boundaries, across which members of the Muslim community are not 'welcome' to step. The enactment of physical, geographical boundaries impacts upon 'emotional geographies' in relation to the way in which Muslims perceive the spaces and places around and outside their communities of abode. ${ }^{54}$ Rather than risk the threat of being attacked, both verbally and physically, many victims and potential victims opt to retreat to 'their own' communities. The fear of discrimination, harassment and violence reinforces these emotional and geographical boundaries whilst contributing to ongoing withdrawal and isolation. Ultimately, it furthers patterns of segregation for 'us' and 'them'. This symbiosis of the individual and the collective is crucial for understanding the community impact of the veil ban.

At the same time though, it is important not to treat members of the ummah as monolithic or psychologically similar with regard to their experiences and understanding of Islamophobia as a form of oppression and violence. There is no single monolithic Muslim community and as a result, no single monolithic Muslim standpoint on the veil ban policy. An understanding of the different layers of identity surrounding the core identity of ummah has significance for understanding the diversity of Muslims' responses to this piece of legislation. Muslim women (and men) are not a homogeneous group: their social, educational and cultural backgrounds, family and occupational situations differ significantly and determine to a large extent their religious affiliation, their integration and relationship with the 'host' community. 55 'This line of thought suggests that experiences and effects of Islamophobia are likely to be shaped by a range of characteristics of the individual such as age, gender, class, ethnicity, sexuality, geographical location and socio-economic status.

50 R A Saunders, 'The Ummah as Nation: A Reappraisal in the Wake of the Cartoons Affair' (2008) 14(2) Nations and Nationalism 303-21.

51 Ibid 6.

52 G Mythen, S Walklate and F Khan, “I'm a Muslim, but I'm not a Terrorist”: Victimisation, Risky Identities and the Performance of Safety' (2009) 49(6) British Journal of Criminology 736-54.

53 B Perry and S Alvi, “We are All Vulnerable”: The in Terrorem Effects of Hate Crimes' (2012) 18(1) International Review of Victimology 57-71.

54 P Hopkins, 'Young Muslim Men's Experiences of Local Landscapes after 11th September 2001' in C Atkinson, P Hopkins and M Kwan (eds), Geographies of Muslim Identities: Diaspora, Gender and Belonging (Ashgate 2007).

55 Ibid 6. 
Recognising the intersectionality of identities and the interplay of different aspects of Muslim identities with other personal, social and situational factors is crucial to understanding the impact of this piece of legislation both individually and collectively.

\section{Conclusions}

This article has examined the significance of the veil ban and its emotional impact upon veiled Muslim women in the West. We have argued that the face veil has come under attack in European domestic policies on the basis that it is a symbol of Islamist fundamentalism, gender inequality and lack of integration. Certainly, these are legitimate state interests in relation to law enforcement. However, although the veil ban may be legal under French and Belgian law, and secularism may be a core feature of European law, the law in question arguably constitutes a human rights violation ${ }^{56}$ and also undercuts individual agency, privacy and self-expression no less than in countries where women are forced to veil. Whether veiling is a compulsory form of dress for women or whether it is outlawed, the impact upon women is the same. Such policies of disciplining and regulating women's bodies are imposed by state authorities and, as such, challenge the autonomy of women to make choices about their bodies and dress. ${ }^{57}$

Nor can it be forgotten that the veil ban is but one manifestation of the harmful effects of Islamophobia. Muslim women - whether veiled or not - can still be subjected to discriminatory treatment and harassment at home, in schools and in wider society. ${ }^{58}$ They may face multiple and simultaneous discrimination, not only on the basis of their religion and gender, but also due to their ethnicity, age, class, disability, sexual orientation, nationality and political ideology. An informed awareness of the impact of the veil ban policy illustrates the multiplicative and intersectional nature of the potential discriminations involved. Muslim women need to become more economically, politically and legally empowered so they can more fully participate in mainstream society and in making decisions about their own lives. Given the emphasis placed on imposing the veil ban as part of a strategy to achieve women's equality, law makers in France and Belgium should consider whether the veil ban has any less desirable consequences for Muslim women.

The consequences of the veil ban policy are threefold. First, the veil ban oppresses women who want to wear the veil by depriving them from having control over their bodies and the way they dress. Clearly, this law is not a 'religious-blind' piece of legislation; rather it attacks 'Islam' through the religious code of dress for Muslim women. Secondly, the law stigmatises veiled Muslim women as 'criminals' and fosters 'otherness' in the form of antiMuslim prejudice. In this light, the veil ban policy - including support for state veil bans is fertile ground for anti-Muslim hate crimes and other such incidents in the public sphere. Even if not explicitly inciting hate-motivated violence, the law in its application contributes to a climate of intolerance and to mounting tensions between Islam and the West. Last but not least, the veil ban affects the wider Muslim community in the West through reference to the notion of ummah (the worldwide community of Muslim believers). Feelings of social exclusion, isolation and forced segregation are coupled by feelings of rejection by mainstream society. These realities of discrimination, fear, vulnerability, social and economic exclusion - informed by an ideological Islamophobia - have not appeared as a result of the veil ban alone. High unemployment rates, discrimination in development

56 Under article 9 of the European Convention on Human Rights (freedom of thought, conscience and religion).

57 See J Zine, 'Unveiled Sentiments: Gendered Islamophobia and Experiences of Veiling among Muslim Girls in a Canadian Islamic School (2006) 39(3) Equity and Excellence in Education 239-42.

58 Wing and Smith (n 15). 
opportunities and the overall isolation of Muslim communities in Europe in parallel with the racist essentialising of their 'Muslimhood' have alienated the Muslim population from the rest of European society.

Ultimately, Islamophobia as an ideology tars all Muslims with the fundamentalist brush and legitimises discrimination towards those Muslims who do not embrace the values, norms and behaviour of the dominant identity. The veil ban demonstrates that anti-Muslim discourse is no longer confined to far-right political parties but is increasingly found within the mainstream of the political spectrum.

In 2009, the former French President Nicolas Sarkozy announced that the full-face veil is incongruous with French values, commenting that 'in our country, we cannot accept that women be prisoners behind a screen, cut off from all social life, deprived of all identity'.59 Such comments demonstrate that rhetoric of this sort has become increasingly legitimised, as it has moved from the far right of the political spectrum to the mainstream. These are issues affecting not simply the Muslim community but wider society as well. In this regard, victims are not only those directly targeted, such as Muslim women who are forced to remove their veils. In essence, society as a whole loses out when discrimination is legitimised because it undermines the fundamental values of a democratic society.

59 A Chrisafis, 'Nicolas Sarkozy says Islamic Veils are not Welcome in France' The Guardian (London, 22 June 2009) <www.guardian.co.uk/world/2009/jun/22/islamic-veils-sarkozy-speech-france>. 